Slađana B. Tanasković1*, Mirjana Antonijević-Nikolić2 Branka Dražić ${ }^{1}$

1 University of Belgrade, Faculty of Pharmacy, Belgrade, Serbia, ${ }^{2}$ Higher Medical and Business-technological School of Professional Studies, Šabac, Serbia
Scientific paper

ISSN 0351-9465, E-ISSN 2466-2585

UDC:631.81.095.338:546.73

doi: $10.5937 /$ ZasMat $1801051 \mathrm{~T}$

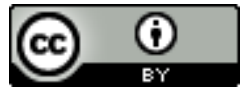

Zastita Materijala 59 (1)

$51-55$ (2018)

\title{
New mixed ligand Co(II) complexes- synthesis, characterization and antimicrobial activity
}

\begin{abstract}
A new complexes with general formula $\left[\mathrm{Co}_{2}(X)_{2} t p m c\right]\left(B F_{4}\right)_{2} \cdot Y\left(X=F^{-}, Y=\mathrm{CH}_{3} \mathrm{CN} ; X=\mathrm{Br}, Y=\mathrm{H}_{2} \mathrm{O}\right.$; tpmc = N,N',N",N"'- tetrakis(2-pyridylmethyl)-1,4,8,11-tetraazacyclotetradecane), were isolated and their composition, some of physical and chemical properties and their tentative geometries were evaluated based on: elemental analysis $(C, H, N)$, conductometric and magnetic measurements, spectroscopic data (UV/Vis, IR) respectively. Then, we compared synthesized complexes with early described chloro analogous. Both complexes are binuclear with proposed chair conformation of macrocycle. Complex compounds were also preliminary assayed in vitro toward some Gram (+) and Gram (-) bacteria, fungi and mould together with the starting material for the synthesis (ligands, simple salts and solvents) as test substances. In some cases certain antimicrobial activity of the complexes was detected. Minimal inhibitory concentration suppressing the visible growth of bacteria was determined. Both investigated complexes showed a moderate activity against strains of bacteria and were inactive against the tested fungi and mould. Under the same conditions and applied the same concentration of the control group did not show activity.
\end{abstract}

Keywords: antimicrobial activity, Co(II) complexes, pendant octaazamacrocycle.

\section{INTRODUCTION}

Polyazamacrocyclic ligands and their metal complexes are an attractive field of investigation due to their numerous unusual structural and biological properties. They are potential candidates for biological and medical application. Some of them are models for the active centers of metaloenzymes, potentially are bioactive and could be used as drugs, catalists etc. The macrocyclic ligands and their complexes are widely used in various fields of science and technology, for example, as coatings of various materials, catalysts, anti-microbial materials, generation of electric energy (a solar cell), in medicine and others. Can be used independently or in the form of thin layers on metallic, ceramic, polymeric materials and composites Particularly interesting are mixed-ligand complexes with various co-ligands and depending on the structure and the number of co-ligands,

\footnotetext{
*Corresponding author: Slađana Tanasković

E-mail: sladjana@pharmacy.bg.ac.rs

Paper received: 18. 09. 2017.

Paper accepted: 03. 11. 2017.

Paper is available on the website: www.idk.org.rs/journal
}

selection of metal and polyazamacrocyclic ligands, these complexes showed specific coordination behaviors and interesting structurs: have an ability to form mono-, bi- or tetranuclear complexes; they have a strong affinity towards various anions to form anion-bridged complexes and polyazamacrocyclic ligands are able to stabilize metals in their lower oxidation states. Mixed ligand $\mathrm{Co}$ (II) complexes with octadentate ligand with 2-pyridylmethyl groups as pendant arms, tpmc (Figure 1) and various monodentate or helate ligands were intensively studied [1-4]. For many of them chair conformation was proposed. Althought the majority of these compounds were air stable, it was dificult to isolate the suitable single crystals. The cristals usually slowly lose shine by staying on the air and decomposed during exposition to X-ray beams at room temperature. Despite carefully chosen and controlled condition of synthesis, it is difficult to confirm the structure Xray analysis. Up to now the $\mathrm{X}$-ray analysis was performed for only two of them: $\mu$-oxalato complex having tpmc in boat conformation [2] and $\left[\mathrm{CO}_{2}(\mathrm{Cl})_{2} \mathrm{tpmc}\right]\left(\mathrm{BF}_{4}\right)_{2}$ complex [5] with macrocycle (tpmc) in chair conformation. The geometry around each $\mathrm{Co}(\mathrm{II})$ in the second complex is distorted trigonal bipyramide formed by two cyclam nitrogen 
atoms and two nitrogens from pyridyl groups (exo coordination). The fifth coordination site is occupied by chloro anion.

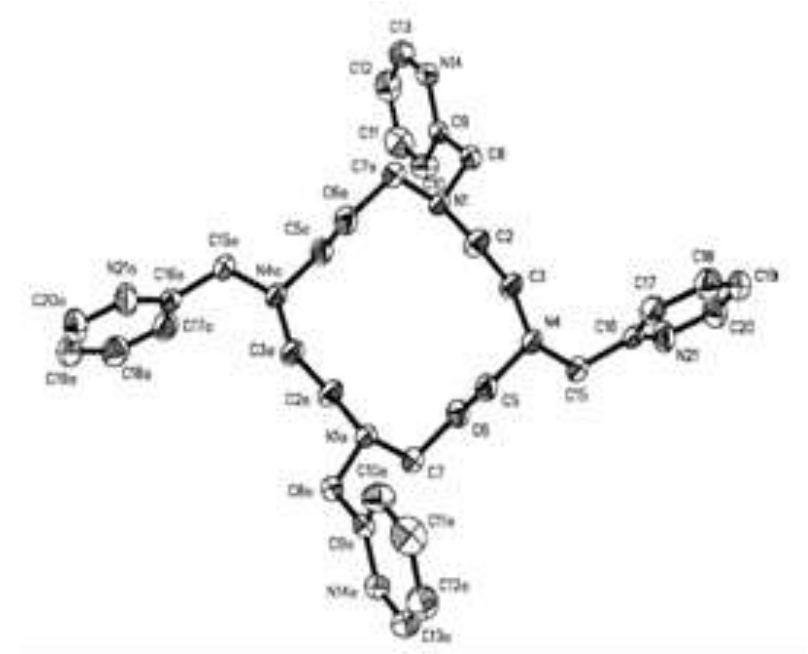

Figure 1. Structure of octaazamacrocyclic ligand tpmc

Slika 1. Struktura oktaazamakrocikličnog liganda tpmc-a

Continuing these investigations, here we report the preparation and characterization of two new Co(II) complexes: fluoro and bromo analogous, some of their physical and chemical properties and preliminary test for microbiological activity. In addition, their properties are compared with previously described macrocyclic Co(II) complex with hloro anion as co-ligand.

\section{EXPERIMENTAL}

Ligand tpmc was prepared and purified as described in the literature [6]. The other chemicals: $\mathrm{CoF}_{2}, \mathrm{CoBr}_{2}$ and $\mathrm{NaBF}_{4}$ as p.a. commercial products were provided by Sigma Aldrich, USA.

$$
\begin{aligned}
& {\left[\mathrm{Co}_{2}(X)_{2} t p m c\right]\left(B F_{4}\right)_{2} \cdot Y:\left(X=F^{-}, Y=C_{3} C N ;\right.} \\
& \left.X=B r, Y=H_{2} \mathrm{O}\right)
\end{aligned}
$$

General procedure. $\mathrm{CoF}_{2} / \mathrm{CoBr}_{2}(0.048 \mathrm{~g} / 0.109$ $\mathrm{g}, 0.5 \mathrm{mmol}$ ) were dissolved in minimum amount of $\mathrm{CH}_{3} \mathrm{OH}$ and after that, a suspension of tpmc $(0.141$ g, $0.25 \mathrm{mmol}$ ) in $\mathrm{CH}_{3} \mathrm{OH}$ was added. Reaction mixture was continuously stirred and refluxed on water bath $\left(80^{\circ} \mathrm{C}\right)$ for the next 2 hours, concentrated to $1 / 4$ of initial volume and left in refrigerator overnight. Microcrystalline product was separated by suction, dried at room temperature, washed properly with small portions of cold water, and the procedure is repeated until pure product is obtained (checked using microscope).

Synthesis iodo derivatives was obtained an oily black-green product which recrystallization was difficult.

\subsection{Analytical methods}

Elemental analyses were performed by standard methods in the Centre for instrumental analyses ICTM in Belgrade.

Electronic absorption spectra of complex solution in $\mathrm{CH}_{3} \mathrm{CN} \quad\left(\mathrm{c}=1 \cdot 10^{-3} \mathrm{~mol} / \mathrm{dm}^{3}\right)$ were recorded on GBC UV/Vis spectrophotometer Cintra 20.

IR spectra were recorded on NICOLET 6700 FTIR (ATR technique) in the range $400-4000 \mathrm{~cm}^{-1}$.

Molar conductivities were measured on conductometer HANNA instruments $\mathrm{HI} 8820 \mathrm{~N}$ (at $\left.23 \pm 2^{\circ} \mathrm{C}\right)$ in $\mathrm{CH}_{3} \mathrm{CN}\left(\mathrm{c}=1 \cdot 10^{-3} \mathrm{~mol} / \mathrm{dm}^{3}\right)$.

Magnetic susceptibilities were measured on magnetic balance MSB-MKI, Sherwood Scientific Ltd., England at room temperature $\left(23 \pm 2^{\circ} \mathrm{C}\right)$. For both complexes the data were corrected for diamagnetism using Pascal's constants [7].

\section{Antimicrobial test}

For the preliminary antimicrobial test, the agar well diffusion method was applied. For determination of antimicrobial activity the following six cultures of microorganisms: Gram(+) bacteriaMicrococcus lysodeikticus ATCC 4698, Staphylococcus aureus ATCC 25923, Bacillus subtilis ATCC 6633 and Bacillus cereus, Gram (-)bacterium- Escherichia coli ATCC 25922, fungi Candida albicans ATCC 24433 and mould Aspergillus niger ATCC 12066 were used. Bacteria were cultivated on Mueller-Hinton agar and fungi on Sabouraud dextrose agar. Inoculation was performed by mixing $0,1 \mathrm{~mL}$ of the microorganism suspension in physiological solution $(0,8 \mathrm{~g} / \mathrm{L} \mathrm{NaCl})$ with $20 \mathrm{~mL}$ of the molten cold medium [8]. In the inoculated agar plates the holes $(\varnothing 0,8 \mathrm{~cm})$ were formed and $100 \mu \mathrm{L}$ of the tested solutions $(1 \mathrm{mg} / \mathrm{mL}$ in DMSO) were separately introduced in the holes. Neither of the complexes showed antifungal activity. Apart from the complexes A,B, tpmc and starting salts were tested. Incubation temperature was: $37^{\circ} \mathrm{C}$ for bacteria and $28^{\circ} \mathrm{C}$ for fungi. The antibacterial activities of complexes $\mathbf{1}$ and $\mathbf{2}$ were quantified by the dilution method in agar (the minimum inhibition concentration was determined, MIC) $[9,10]$

The initial concentration of the complexes was $8 \mathrm{mg} / \mathrm{mL}$ in DMSO. This solution was doubly diluted to give concentrations in the range $8-0.125$ $\mathrm{mg} / \mathrm{mL}$. $0.5 \mathrm{~mL}$ of the solution of the tested substances was mixed with $9.5 \mathrm{~mL}$ of melted and cooled nutrition agar. The bacteria were seeded on the surface of the agar plate. After incubation for 24 $\mathrm{h}$, the $M I C$ values were determined as the lowest concentration of the complex preventing visible growth of the bacteria. 


\section{RESULTS AND DISCUSSION}

[C $\mathrm{Co}_{2}(\mathrm{~F})_{2}$ tpmc] $\left(\mathrm{BF}_{4}\right)_{2} \cdot \mathrm{CH}_{3} \mathrm{CN}$ (A). Yield: $48 \%$; Anal. Calcd. for $\mathrm{C}_{36} \mathrm{H}_{47} \mathrm{~N}_{9} \mathrm{Co}_{2} \mathrm{~B}_{2} \mathrm{~F}_{10}(\mathrm{FW}=935.306)$ C, 46.23; H, 5.07; N, 13.48. Found: C, 46.63; H, $5.17 ; \mathrm{N}, 13.11$.

$\left[\mathrm{CO}_{2}(\mathrm{Br})_{2} \mathrm{tpmc}\right]\left(\mathrm{BF}_{4}\right)_{2} \cdot \mathrm{H}_{2} \mathrm{O}$ (B). Yield: $73 \%$; Anal. Calcd. for $\mathrm{C}_{34} \mathrm{H}_{46} \mathrm{~N}_{8} \mathrm{Co}_{2} \mathrm{Br}_{2} \quad \mathrm{~B}_{2} \mathrm{~F}_{8} \quad(\mathrm{FW}=$ 1034.052): C, 39.49; H, 4.48; N, 10.84. Found: C, 39.16; H, 4.62; N, 10.74 .

Solubility of the complexes $A, B$ : well soluble in $\mathrm{CH}_{3} \mathrm{CN}$, sparingly in DMSO and DMF, insoluble in $\mathrm{CH}_{3} \mathrm{OH}, \mathrm{C}_{2} \mathrm{H}_{5} \mathrm{OH}$ and cold water. The complexes did not melted or decomposed up to $250^{\circ} \mathrm{C}$ (check with the hot plate equipped with microscope). Molar electrical conductivity in $\mathrm{CH}_{3} \mathrm{CN}$ of $265 \mathrm{Scm}^{2} \mathrm{~mol}^{-1}$ is in agreement with a 1:2 electrolyte type (literature range is $220-300 \mathrm{Scm}^{2} \mathrm{~mol}^{-1}$ ) [11]. In the electronic absorption spectrum (Figure 2) of complexes $\left[\mathrm{CO}_{2}(\mathrm{~F})_{2}\right.$ tpmc] $\left(\mathrm{BF}_{4}\right)_{2} \cdot \mathrm{CH}_{3} \mathrm{CN}$ and $\left[\mathrm{Co}_{2}(\mathrm{Br})_{2} \mathrm{tpmc}\right]\left(\mathrm{BF}_{4}\right)_{2} \cdot \mathrm{H}_{2} \mathrm{O}$ recorded in $\mathrm{CH}_{3} \mathrm{CN}$, maxima at $483 \mathrm{~nm}\left(\varepsilon=119 \mathrm{dm}^{3} \mathrm{~mol}^{-1} \mathrm{~cm}^{-1}\right), 549 \mathrm{~nm}$ $\left(\varepsilon=143 \mathrm{dm}^{3} \mathrm{~mol}^{-1} \mathrm{~cm}^{-1}\right)$ and $589 \mathrm{~nm}\left(\varepsilon=138 \mathrm{dm}^{3} \mathrm{~mol}^{-}\right.$ ${ }^{1} \mathrm{~cm}^{-1}$ ) corresponding to $d-d$ transitions are typical for a high-spin Co(II) complexes. The absorption maximum for CT transitions is at $~ 220-225 \mathrm{~nm}$ $\left(\varepsilon=5500-6700 \mathrm{dm}^{3} \mathrm{~mol}^{-1} \mathrm{~cm}^{-1}\right.$ ) [12]. That maxima positions and the $\varepsilon$ values for complexes $A$ and $B$ are comparable with the data for analogous chloro complex suggesting the same chromophore.

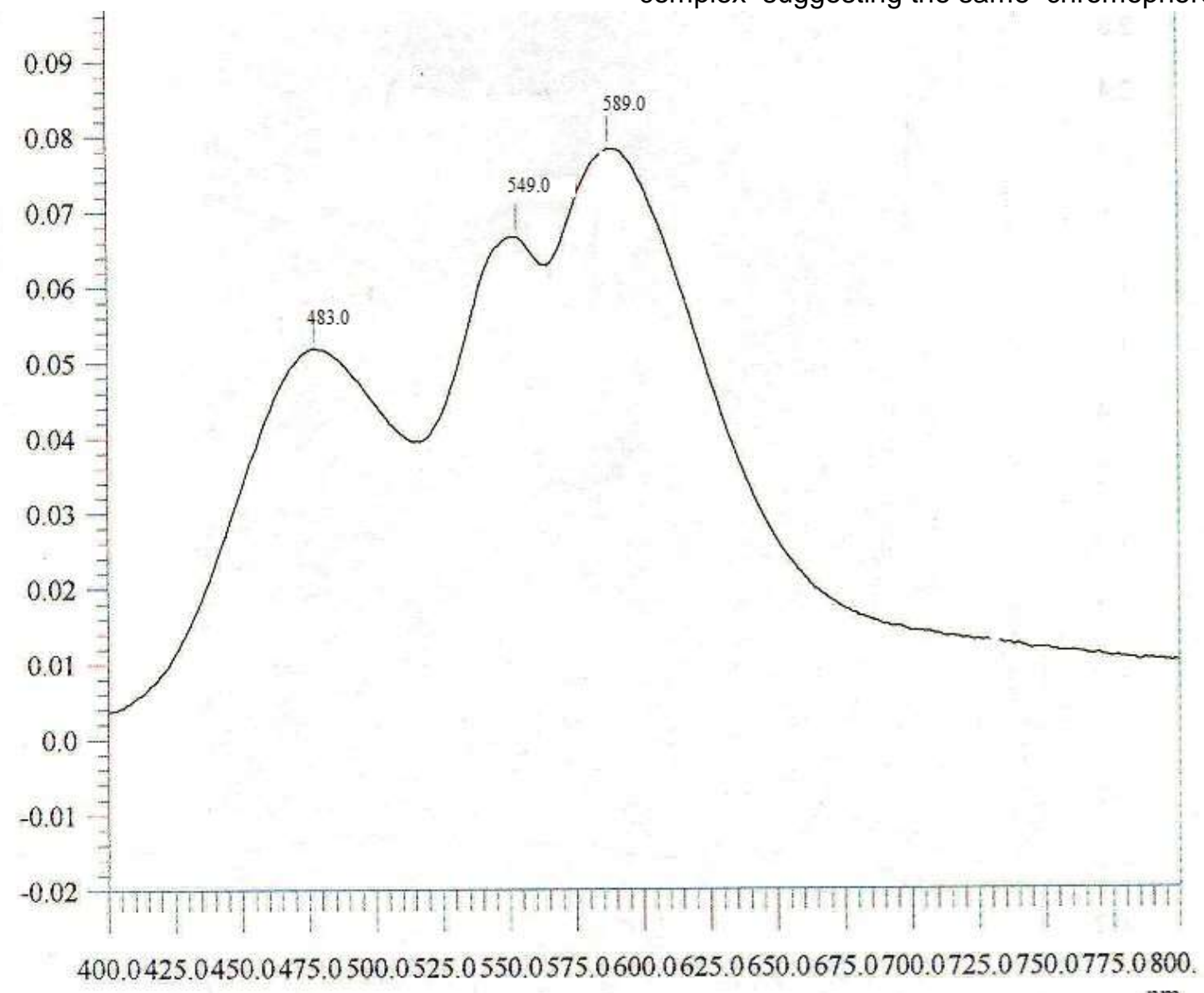

Figure 2. Electronic spectra of $\left[\mathrm{Co}_{2}(X)_{2} t p m c\right]^{2+}\left(X=F^{-}, \mathrm{Br}\right)$

Slika 2. Elektronski spektar kompleksnog jona $\left[\mathrm{Co}_{2}(X)_{2} t p m c\right]^{2+}\left(X=F^{-}, B r\right)$

The magnetic moment at room temperature for the complexes 1 and 2 of $4.21 \mu \mathrm{B}$ and $4,35 \mu \mathrm{B}$ falls in the range 3.96-4.75 $\mu \mathrm{B} / \mathrm{Co}$ (II) found for highspin analogous complexes with 3 unpaired electrons $[13,14]$.

The IR spectrum of the complexes display characteristic bands $\left(\mathrm{cm}^{-1}\right): \mathrm{v}(\mathrm{C}-\mathrm{H})$ at 2952 (medium), $\mathrm{v}\left(\mathrm{BF}_{4}{ }^{-}\right)$at 1072 (strong, sharp); skeletal pyridine vibration from tpmc at 1605 (strong) suggesting coordination of tpmc and the presence of $\mathrm{BF}_{4}^{-}$as counter ion [15]. From all presented data and using models the more probable geometry for both prepared complexes are shown in Scheme 1. 


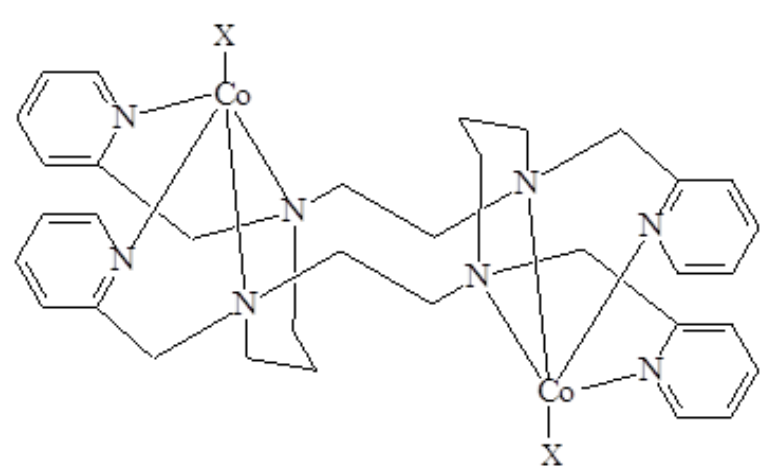

Scheme 1. Proposed geometry of the complex cation $\left[\mathrm{Co}_{2}(X)_{2} \mathrm{tpmc}^{2+},\left(\mathrm{X}=\mathrm{F}^{-}, \mathrm{Br}\right)^{-}\right)$

Šema 1. Pretpostavljena geometrija kompleksnog katjona $\left[\mathrm{Co}_{2}(X)_{2} t p m c\right]^{2+},\left(X=F^{-}, \mathrm{Br}\right)$

Fluorine is a highly toxic and corrosive element. Bromine, also very toxic, has been used occasionally in water treatment programs. There are few reports of the use of this halogen as an antimicrobial agent. The antimicrobial effectiveness of each halogen compound varies with such factors as availability of the element to react with the cell populations, $\mathrm{pH}$, concentration, contact time, temperature, organic matter and the type and form of microorganism [16].

Synthetized complexes, all ligands and solvents were preliminary also tested against some Gram (+) and Gram (-) bacteria, in $\mathrm{DMSO} / \mathrm{H}_{2} \mathrm{O}$ and certain bacteriostatic activity is detected in both cases. Values of MIC show that complex B is the most effective agent against $M$. lysodeikticus. Complex B shows the greatest antimicrobial activity against all the four types of test microorganisms (M. lysodeikticus, S. aureus, E. coli, B. subtilis). The antimicrobial study showed that the solvents, ligands and simple salts were inactive up to $400 \mu \mathrm{g}$ $\mathrm{mL}-1$ against all the studied microorganisms under the same conditions and in the same used concentrations. MIC for complexes A, B and earlier prepared chloro analogous are given in Table 1.

Table 1. Minimum inhibitory concentration (MIC), in $\mu \mathrm{g} / \mathrm{mL}$ of the complexes in DMSO

Tabela 1. Minimalna inhibitorna koncentracija (MIC), u $\mu \mathrm{g} / \mathrm{mL}$ kompleksa u DMSO

\begin{tabular}{|c|c|c|c|c|}
\hline \multicolumn{1}{|c|}{ Complex } & M.L. & S.A. & E.C & B.S $^{*}$ \\
\hline$\left[\mathrm{Co}_{2} \mathrm{~F}_{2}\right.$ tpmc $]\left(\mathrm{BF}_{4}\right)_{2} \cdot \mathrm{CH}_{3} \mathrm{CN}$ & 100 & 100 & 100 & 100 \\
\hline$\left[\mathrm{Co}_{2} \mathrm{Cl}_{2}(\mathrm{tpmc})\right]\left(\mathrm{BF}_{4}\right)_{2}[5]$ & 100 & 200 & 200 & 200 \\
\hline$\left[\mathrm{Co}_{2} \mathrm{Br}_{2}\right.$ tpmc $]\left(\mathrm{BF}_{4}\right)_{2} \cdot \mathrm{H}_{2} \mathrm{O}$ & 50 & 100 & 400 & 100 \\
\hline
\end{tabular}

${ }^{*}$ M.L, M. lysodeikticus ATCC 4698; S.A, S. aureus ATCC 25923; E.C, E. coli ATCC 25922; B.S, B. subtilis ATCC 66334.

\section{CONCLUSION}

In these paper two new binuclear cationic Co(II) complexes with octaazamacrocyclic ligand tpmc and $\mathrm{F}^{-} / \mathrm{Br}$ - anions were prepared in good yield. Their composition and geometries were assumed based on elemental analysis, electrical conductivity, spectral properties and magnetic measurements, as well as by comparison with data of related complex previously published. For complexes the same exo coordination of each $\mathrm{Co}$ (II) ion with azamacrocyclic ligand engaging two pyridine $\mathrm{N}$ and two cyclam's $\mathrm{N}$ atoms, and $\mathrm{F}^{-} / \mathrm{Br}^{-}$in trans position is proposed. Selective antibacterial activity towards $\operatorname{Gram}(+)$ bacteria for the complexes was also detected. The best effect on $M$. lysodeikticus shows complex $\left[\mathrm{Co}_{2}(\mathrm{Br})_{2} \mathrm{tpmc}\right]\left(\mathrm{BF}_{4}\right)_{2} \cdot \mathrm{H}_{2} \mathrm{O}$.

\section{Acknowledgement}

This work was partially supported by the Ministry for Science of the Republic of Serbia (Grant No. 172014).

\section{REFERENCES}

[1] H.Harada, M. Kodera, G. Vučković, N. Matsumoto, S. Kida (1991) Preparation and redox chemistry of novel carbonato-bridged cobalt(II) complexes with 1,4,8,11-tetrakis(2-aminoethyl)-1,4,8,11tetraazacyclotetradecane and 1,4,8,11-tetrakis (pyridylmethyl)- 1,4,8,11-tetraazacyclotetradecane, Inorg. Chem., 30,1190-1194.

[2] S.Sovilj, G.Vučković, K.Babić-Samardžija, N. Matsumoto, V.Jovanović, J.Mroziński (1999) Synthesis, Crystal Structure, Magnetic Properties and Cyclic Voltammetry of the Unsymmetric $(\mu$ Oxalato)-[N, N', N", N"'-Tetrakis-(2- Pyridilmethyl)-1, 4,8,11-Tetraazacyclotetradecane]Dicobalt(II) Pekchlorate Trihydrate, J. Synth. React. Inorg. Met.Org.Chem., 29, 785-803.

[3] G.Vučković, M.Šumar, I.Brčeski, V.Leovac, D. Mitić (1999) Biologicaly active dinuclear complexes of cobalt(II) with a pendant octaazamacrocyclic ligand and pseudohalides, J. Serb.Chem. Soc., 64 (3), 191- 198.

[4] G.Vučković, V,Stanić, S.Sovilj, M.AntonijevićNikolić, J.Mroziński (2005) Cobalt(II) complexes with aromatic carboxylates and $\mathrm{N}$-funcionalized cyclam bearing 2- pyridylmethyl pendant arms, J. Serb. Chem. Soc., 70(8-9), 1121-1129.

[5] G.Vučković, S.Tanasković, U.Rychlewska, D. Radanović, J.Mrozinski, M.Korabik (2007) Preparation, characterization and X-ray analysis of $\left[\mathrm{Co}_{2}(\mathrm{Cl})_{2}\right.$ tpmc] $\left(\mathrm{BF}_{4}\right)_{2}$. Comparative structural analysis with the complexes having analogous geometries and ligands, J. Mol. Struc., 827, 80-87.

[6] S-G.Kang, S-J.Kim (2003) Synthesis and Properties of Tetraaza Macrocycles Containing Two 3-Pyridylmethyl, 4-Pyridylmethyl, or Phenylmethyl Pendant Arms and Their Nickel(II) and Copper(II) 
Complexes: Effects of the Pendant Arms on the Complex Formation Reaction, Bull. Korean. Chem. Soc., 24, 269-273.

[7] M.N.Hughes (1987) Comprehensive Coordination Chemistry, Oxford University Press, Oxford, United Kingdom.

[8] J.F.Acar, F.W.Goldstein (1996) Antibiotics in Laboratory Medicine. Disk Susceptibility Test in Lorian 4th ed., Baltimore, NY: Williams and Wilkins b) C.R. Mahon (1995) Manuselis G. Textbook of Diagnostic Microbiology, W.B.Saunders Company Philadelphia.

[9] D.Amsterdam (1996) Antibiotics in Laboratory Medicine. 4th ed., Williams and Wilkins, Baltimore.

[10] H.M.Ericsson, J.C.Sherris (1971) Antibiotic sensitivity testing. Report of an international collaborative study, Acta Pathol. Microbiol. Scand. Suppl., 217, 3.

[11] W.J.Geary (1971) The use of conductivity measurements in organic solvents for the characterisation of coordination compounds, Coord. Chem. Rev., 7, 81-122.

[12] B.P.Lever (1984) Inorganic Electronic Spectroscopy. $2^{\text {nd }}$ ed., Elsevier; Amsterdam.

[13] E.König (1966) Magnetic Properties of Coordination and Organometallic Transition Metal Compounds, Springer-Verlag, Berlin.

[14] G.Vučković, D.Opsenica, S. Sovilj, D. Poleti, M. Avramov-Ivić (1997) Preparation, characterization and redox properties of $0,0^{\prime}$-geometrical isomers of $\mu-\alpha$ and $\mu$ - $\beta$-aminoisobutyrato $\mathrm{Co}(\mathrm{II})$ complexes withN, $\mathrm{N}^{\prime}, \mathrm{N}^{\prime \prime}, \mathrm{N}^{\prime \prime}$-tetrakis(2-pyridylmethyl)1,4,8,11-tetraazacyclotetradecane, J. Coord. Chem., 42, 241-251.

[15] K.Nakamoto (1997) Infrared and Raman Spectra of Inorganic and Coordination Compounds. Part B $5^{\text {th }}$ ed., Willey and Sons, New York.

[16] T.E.Odlaug (1981) Antimicrobial Activity of Halogens, J.Food Protec, 44(8), 608-613

\title{
IZVOD
}

\section{NOVI MEŠOVITO-LIGANDNI KOMPLEKSI Co (II)- SINTEZA, KARAKTERIZACIJA I ANTIMIKROBNA AKTIVNOST}

Pripremlljena su dva nova kompleksa opšte formule $\left[\mathrm{Co}_{2}(X)_{2} \operatorname{tpmc}\right]\left(\mathrm{BF}_{4}\right)_{2} \cdot Y\left(X=F^{-}, Y=\mathrm{CH}_{3} \mathrm{CN} ; X=\right.$ $\mathrm{Br}, Y=\mathrm{H}_{2} \mathrm{O} ; \mathrm{tpmc}=\mathrm{N}, N^{\prime}, N^{\prime \prime}, N^{\prime \prime \prime}-$ tetrakis(2-piridilmetil)-1,4,8,11-tetraazaciklotetradekan), čiji su sastav, neke fizičke $i$ hemijske osobine kao i približne geometrije određene na osnovu elementalne analize $(\mathrm{C}, \mathrm{H}, \mathrm{N})$, konduktometrijskih i magnetnih merenja i spektroskopskih podataka (UV/Vis, IR). Podaci su upoređeni sa ranije sintetisanim i opisanim hloro analogom. Oba nova kompleksa Co(II) su dinuklearna sa pretpostavljenom egzo koordinacijom makrocikla u konformaciji stolice. Kompleksi su preliminarno testirani na neke Gram (+), Gram (-) bakterije, plesni i kvasce zajedno sa startnim supstancama za sintezu (ligandima, prostim solima i rastvaračima) koje su služile kao test supstance. Određivana je minimalna inhibitorna koncentracija koja sprečava rast bakterija. U nekim slučajevima je nađena izvesna antimikrobna aktivnost. Oba kompleksa su pokazala aktivnost prema bakterijama ali su inaktivni prema gljivicama i kvascima dok je pod istim uslovima $i$ istim primenjenim koncentracijama kontrolna grupa bila neaktivna.

Ključne reči: antimikrobna aktivnost, Co(II) kompleksi, pendantni oktaazamakrocikli.

\author{
Naučni rad \\ Rad primljen: 18. 09. 2017. \\ Rad prihvaćen: 03. 11. 2017. \\ Rad je dostupan na sajtu: www.idk.org.rs/casopis
}

(c) 2018 Authors. Published by Engineering Society for Corrosion. This article is an open access article distributed under the terms and conditions of the Creative Commons Attribution 4.0 International license (https://creativecommons.org/licenses/by/4.0/) 